\title{
Settlement and early post-settlement survival in the recruitment of Mulinia lateralis (Bivalvia)*
}

\author{
Mark W. Luckenbach \\ Belle W. Baruch Institute for Marine Biology and Coastal Research \\ and \\ Department of Biology, University of South Carolina, Columbia, South Carolina 29208, USA
}

\begin{abstract}
Recruitment of benthic invertebrates involves settlement and early post-larval survival. In soft-sediment habitats these 2 events generally have not been distinguished despite the fact that they may lead to different interpretations of the processes affecting recruitment. Settlement and early postlarval survival of the bivalve Mulinia lateralis (Say) in a natural infaunal community were recorded and the 2 phenomena distinguished. $M$. lateralis settled in large numbers (514 $0.01 \mathrm{~m}^{-2}$ ) into an intertidal infaunal community characterized by high but variable densities of the tubicolous polychaete Diopatra cuprea (Bosc). Settlement density was variable but did not differ between sites with and without $D$. cuprea tubes. Early post-larval (within $1 \mathrm{mo}$ ) survival/persistence was lower in sites with high densities of $D$. cuprea and in sites which were bounded by high densities of $D$. cuprea than in sites without $D$. cuprea. Rapid changes in $M$. lateralis abundance after settlement and differential survival between. microhabitats led to distribution patterns which after 1 mo differed substantially from initial settlement patterns. Attempts to evaluate processes which lead to observed recruitment patterns must first distinguish between these 2 events.
\end{abstract}

\section{INTRODUCTION}

Recruitment patterns play an important role in determining community structure. The process of recruitment into a habitat consists of at least 2 components: (1) arrival in the habitat and (2) early survival in the habitat (Thorson, 1966). Only recently, however, has this distinction been made in data collection for sessile hard substrate benthos (Grosberg, 1981: Keough and Downes, 1982) and for mobile epibenthos (Fretter and Manly, 1977; Sarver, 1979; Cameron and Schroeter, 1980; Highsmith, 1982). Processes occurring during these phases generally have not been distinguished in marine infaunal communities, and recruitment has been defined operationally as settlement followed by post-settlement survival and growth to a size retained on a sieve, often $\geq 500 \mu \mathrm{m}$ (but see Williams, 1980a, b for an exception in a gravel habitat). In order to understand processes which affect recruitment and subsequent population structure it is necessary to distin-

\footnotetext{
- Contribution No. 536 from the Belle W. Baruch Institute for Marine Biology and Coastal Research

guish between patterns of settlement and early postsettlement survival.

Settlement of benthic invertebrates may be affected by several factors: (1) larval availability (Thorson, 1966; Hannan, 1981; Grosberg, 1982), (2) active selection by settling larvae (reviewed by Meadows and Campbell, 1972; Scheltema, 1974; Crisp, 1976; Lewis, 1977), and (3) passive accumulation and dispersion of settling larvae (Hannan, 1981; Eckman, 1983). Frequently, observed patterns of recruitment are attributed to settlement and inferences are made concerning one of these factors (but see Keough and Downes, 1982 for an exception). Sampling methods used are, however, seldom adequate to detect settlement events. Two conditions must be fulfilled in order to observe settlement patterns of benthic invertebrates (Williams, 1980a). First, settlement-sized individuals must be observed which, in soft sediments, requires that small sieve sizes be used. Second, the time between settlement and sampling must be small. Both of these conditions are met rarely in recruitment studies of marine infaunal benthos.

Mulinia lateralis (Say), a small infaunal bivalve, is an opportunist that has highly variable annual recruit- 
ment (Boesch, 1973; Boesch et al., 1976; Virnstein, 1977). Such variability could result from year-to-year differences in larval availability and settlement, or in variation in post-settlement survival. Here I report on the recruitment of $M$. lateralis into a heterogeneous, intertidal, soft-bottom community and distinguish between the patterns of settlement and early postsettlement survival as a function of the heterogeneity

\section{STUDY SITE}

The study site was located on a low intertidal mudflat along Debidue Creek in the North Inlet marsh near Georgetown, South Carolina, USA $\left(33^{\circ} 19^{\prime} \mathrm{N}, 79^{\circ}\right.$ $10^{\prime} \mathrm{W}$ ). Surface salinity in Debidue Creek ranged from 30 to $35 \%$. The habitat into which this recruitment event was recorded is characterized by high but variable densities of the tube-building onuphid polychaete Diopatra cuprea (Bosc). The large, conspicuous tubes project above the sediment surface and add considerable structural heterogeneity to the habitat. A $10 \times 50 \mathrm{~m}$ portion of the mudflat contains a large number of $D$. cuprea tubes ranging from 0 to 15 tubes $0.01 \mathrm{~m}^{-2}$. The sediment is sandy mud with median grain size $=148 \mu \mathrm{m}$ (2.76 phi); silts and clays $(<63$ $\mu \mathrm{m})$ comprise $12 \%$ by weight. Because access to the marsh is limited, the study site was undisturbed.

\section{INITIAL FINDINGS}

Initial sampling revealed that juvenile Mulinia lateralis, ranging in shell length from 200 to $700 \mu \mathrm{m}$ with a modal size of $350 \mu \mathrm{m}$, were less abundant at sites with Diopatra cuprea tubes than at sites without worm tubes. Sites with high densities of worm tubes $(\geq$ $10 \cdot 0.01 \mathrm{~m}^{-2}$ ) had a mean density of $22.3 \cdot 0.01 \mathrm{~m}^{-2} \pm$ $18.5(\mathrm{SD})(\mathrm{N}=4)$ juvenile $M$. lateralis while sites without $D$. cuprea had mean densities of $145 \cdot 0.01$ $\mathrm{m}^{-2} \pm 13.1(\mathrm{SD})(\mathrm{N}=4)$ juvenile $M$. lateralis (Student's $t$-test, $p=0.01$ ). The differences in abundances between the sites may reflect variation in settlement or in very early mortality. The goal of this research was to distinguish between these possibilities.

\section{METHODS}

Nearly $100 \%$ of Diopatra cuprea tubes contain live worms, and old unoccupied tubes are easily recognized by color and texture (Mangum et al., 1968; own obs.). Tubes provide an accurate means of counting these worms, and hereafter, reference to tubes indicates occupied tubes. Four types of sites were selected for sampling based upon the densities of $D$. cuprea (Fig. 1). Local sample sites were approximately $0.01 \mathrm{~m}^{2}$ and contained either high densities of $D$. cuprea $(\geq 9$

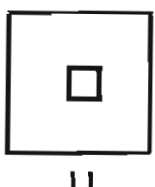

LL

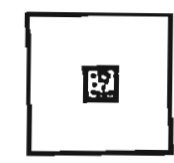

LH

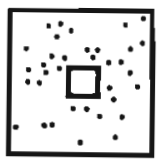

HL

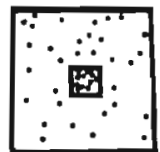

$\mathrm{HH}$
Fig. 1. Diopatra cuprea density treatments. LL: low regional, low local densities; LH: low regional, high local density; HL: high regional, low local densities; $\mathrm{HH}$ : high regional, high local densities

tubes) or no $D$. cuprea. The area of the sites are approximate because natural clumps of $D$. cuprea vary in size and shape. Sites were selected with clumps as close to $0.01 \mathrm{~m}^{2}$ as possible. Subsampling procedure, described below, standardized estimates of post-larval densities within these sites. In addition, the $0.25 \mathrm{~m}^{2}$ regions around these sites were characterized as having either high ( $\geq 25$ tubes) or low ( $\leq 3$ tubes) densities of $D$. cuprea. The combination of local density (high or none) with regional density (high or low) resulted in 4 treatments of natural densities of $D$. cuprea (Fig. 1). These 4 spatial arrangements of $D$. cuprea tubes were used to permit distinction between local and regional effects of the tubes on the settlement and survival of Mulinia lateralis. Ten regions of the mudflat with $D$. cuprea densities corresponding to each of the treatments were located and labelled in the spring of 1981 prior to the settlement of $M$. lateralis.

To detect settlement of Mulinia lateralis, plankton and benthos samples were taken beginning May 1981 at daily or not less frequently than $4 \mathrm{~d}$ intervals. Two plankton samples, taken with 2 min oblique tows using a $102 \mu \mathrm{m}$ mesh net $(50 \mathrm{~cm}$ diam. mouth) were sorted for bivalve larvae. A malfunctioning flowmeter caused estimates of larval abundance to be qualitative only. Replicate samples of surface sediment, taken near the treatments, were sieved on $105 \mu \mathrm{m}$ mesh screen and examined. Density estimates for larval and post-larval $M$. lateralis were based upon counts per subsample (replicate $2 \mathrm{ml}$ aliquots for plankton and one $8.2 \mathrm{~cm}$ diam. Petri dish for benthos) and were ranked from 0 (none present) to 4 (very abundant). Since the intent of these samples was to reveal the time of settlement and not the relation between larval and post-larval abundances, relative density estimates were adequate.

Identification of post-larval Mulinia lateralis was accomplished by rearing field collected individuals in the lab until they were easily identifiable $(>500 \mu \mathrm{m})$. Attempts to maintain larvae through metamorphosis were unsuccessful. Pediveligers were identified by comparison with early post-larval bivalves and with 
Chanley and Andrews (1971). Larval and post-larval identification was aided by low diversity of bivalves in the study area at the time.

Shortly after settlement (4 to 8 d), 5 replicates of each treatment were sampled to determine settlement abundances and distribution of Mulinia lateralis. All samples were taken from the central $0.01 \mathrm{~m}^{2}$ region of the treatments using a $1.5 \mathrm{~cm}$ diam. core. Eight such cores were taken within each treatment replicate for a total of 40 cores treatment. One month after the initial sampling, the remaining 5 treatment replicates were sampled in the same fashion to determine early postsettlement survival. All samples were preserved in the field in $10 \%$ buffered formalin with Rose Bengal stain. Samples were sieved on a $105 \mu \mathrm{m}$ screen, and all $M$. lateralis juveniles were counted and measured to the nearest $40 \mu \mathrm{m}$ with an ocular micrometer.

A 2-way nested analysis of variance (Sokal and Rohlf, 1969) was used to test the effects of local and regional densities of Diopatra cuprea. The combined treatment effect was represented by the cross term between the local and regional densities. Replicate cores were nested within treatments. Appropriate Ftests were determined using expected mean square errors derived by the method of Kirk (1982, p. 390). Where significant effects were observed, Scheffé a posteriori Multiple Contrast Tests (Sokal and Rohlf, 1969) were performed to identify significant differences among means.

\section{RESULTS}

Mulinia lateralis settlement occurred in a distinctive pulse of 1 to $4 \mathrm{~d}$ (Fig. 2). Larvae first appeared in plankton samples on May 30 and were among the most abundant members of the plankton in samples taken on May 30, June 1 and June 6. Benthic samples from June 1 until June 9 contained only occasional $M$. lateralis. Samples taken on June 13 had relatively

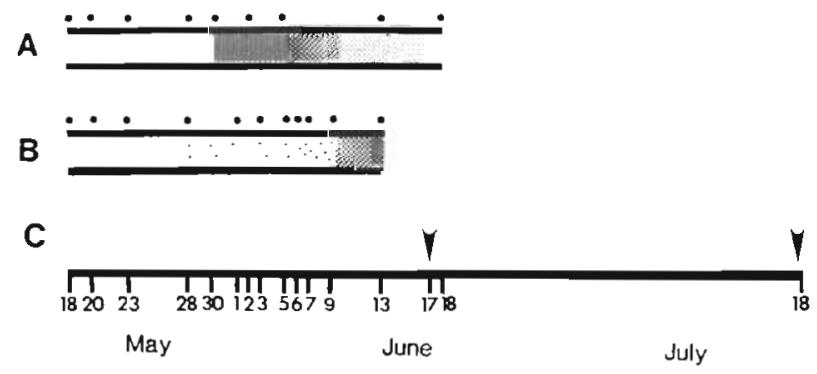

Fig. 2. Mulinia lateralis. Occurrence of larvae and post-settlement juveniles. (A) Planktonic larvae; actual sample dates; degree of shading: qualitative density estimates. (B) Benthic spat, same symbols. (C) Quantitative benthic cores; arrows: sample dates lower densities of $M$. lateralis larvae in the plankton and high densities of metamorphosed juveniles (i.e. without velum) in surface sediments. Settlement of $M$. lateralis therefore occurred primarily between June 9 and June 13.

Half of the treatments were sampled on June 17, the first day after settlement with sufficiently low tides. These samples, taken within 4 to $8 \mathrm{~d}$ after settlement, had mean abundances of Mulinia lateralis within the treatments ranging from $488 \cdot 0.01 \mathrm{~m}^{-2}$ to 563 $0.01 \mathrm{~m}^{-2}$ (Table $1 \mathrm{~A}$ ). ANOVA indicated that there was

Table 1. Mulinia lateralis abundance (mean $\pm \mathrm{SD} \times 0.01 \mathrm{~m}^{-2}$ ) in each Diopatra cuprea treatment. (A) June 17, 4 to $8 \mathrm{~d}$ postsettlement; (B) July 18, approximately 35 d after settlement. Means based on 6 to $81.5 \mathrm{~cm}$ diameter cores per site at 5 sites per treatment for a total of $\mathrm{N}$ samples per estimate. In $\mathrm{B}$, means connected by a vertical line are not significantly different by Scheffé a posteriori Multiple Contrast Test $(p \leq 0.05$ )

\begin{tabular}{|c|c|c|}
\hline \multicolumn{3}{|l|}{ (A) } \\
\hline $\begin{array}{l}\text { Treatment- } \\
\text { Diopatra density }\end{array}$ & $\begin{array}{c}\text { Mulinia } \\
\text { abundance }\end{array}$ & $\mathrm{N}$ \\
\hline $\begin{array}{l}\text { Low local } \\
\text { Low regional }\end{array}$ & $572 \pm 312$ & 39 \\
\hline $\begin{array}{l}\text { Low local } \\
\text { High regional }\end{array}$ & $501 \pm 293$ & 39 \\
\hline $\begin{array}{l}\text { High local } \\
\text { Low regional }\end{array}$ & $540 \pm 254$ & 33 \\
\hline $\begin{array}{l}\text { High local } \\
\text { High regional }\end{array}$ & $496 \pm 210$ & 37 \\
\hline \multicolumn{3}{|l|}{ (B) } \\
\hline $\begin{array}{l}\text { Treatment- } \\
\text { Diopatra density }\end{array}$ & $\begin{array}{c}\text { Mulinia } \\
\text { abundance }\end{array}$ & $N$ \\
\hline $\begin{array}{l}\text { Low local } \\
\text { Low regional }\end{array}$ & $255 \pm 77$ & 40 \\
\hline $\begin{array}{l}\text { Low local } \\
\text { High regional }\end{array}$ & $158 \pm 25$ & 40 \\
\hline $\begin{array}{l}\text { High local } \\
\text { Low regional }\end{array}$ & $105 \pm 33$ & 40 \\
\hline $\begin{array}{l}\text { High local } \\
\text { Low regional }\end{array}$ & $159 \pm 34$ & 40 \\
\hline
\end{tabular}

no effect of treatment or its components, local and regional Diopatra cuprea densities, on $M$. lateralis abundance (Table 2A). However, there was a significant amount of variation between replicates of the treatments (Table 2A).

Modal size of Mulinia lateralis sampled on June 17 was $190 \mu \mathrm{m}$. This is assumed to be very close to the actual settlement size for 2 reasons: (1) very few smaller juveniles were ever collected, including the June 13 samples, and (2) pediveligers ranged from approxi- 
mately 150 to $190 \mu \mathrm{m}$. There was no difference $(p>0.1$ Kolmogorov-Smirnov test; Hollander and Wolfe, 1973, p. 219) in the size composition of $M$. lateralis within the treatments (Fig. 3). Size frequencies of $M$. lateralis within treatments with Diopatra cuprea were pooled and reported as 'High Density Diopatra' (Fig. 3) to facilitate comparisons with later abundance data.

Samples taken 1 mo later, on July 18, showed that Mulinia lateralis abundances had declined in all 4 treatments, with means ranging from $105 \cdot 0.01 \mathrm{~m}^{-2}$ to $255 \cdot 0.01 \mathrm{~m}^{-2}$ (Table $1 \mathrm{~B}$ ). ANOVA revealed a very significant $(p<0.005)$ effect of the local $\times$ regional cross term, i.e. the combined treatment term (Table 2B). Mean M. lateralis abundances in the three treatments with Diopatra cuprea differed from that in sites without $D$. cuprea $(p<0.05$; Scheffé Multiple Contrast Test). In the 3 treatments containing $D$. cuprea, $M$. lateralis abundarces averaged only $55 \%$ of the abund-

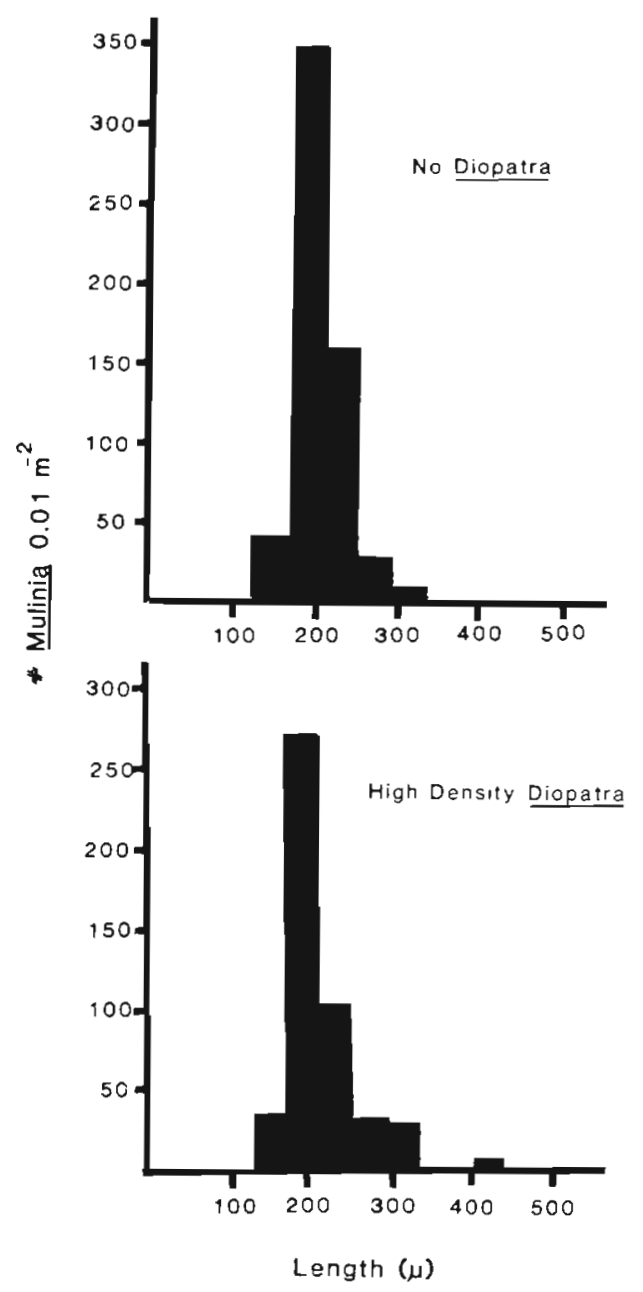

Fig. 3. Mulinia lateralis. Size-frequencies on 17 June, less than $1 \mathrm{wk}$ after settlement. The 3 treatments containing Diopatra cuprea are pooled and reported as 'High Density Diopatra'
Table 2. Modified 2-way nested ANOVA tables. trt: treatment or local $\times$ region cross term. Significance levels: ns $p \geq 0.05$; - $p \leq 0.05_{i} \cdots p \leq 0.005$. (A) Analysis of data 4 to $8 \mathrm{~d}$ postsettlement. (B) Analysis of data approximately $35 \mathrm{~d}$ after settlement

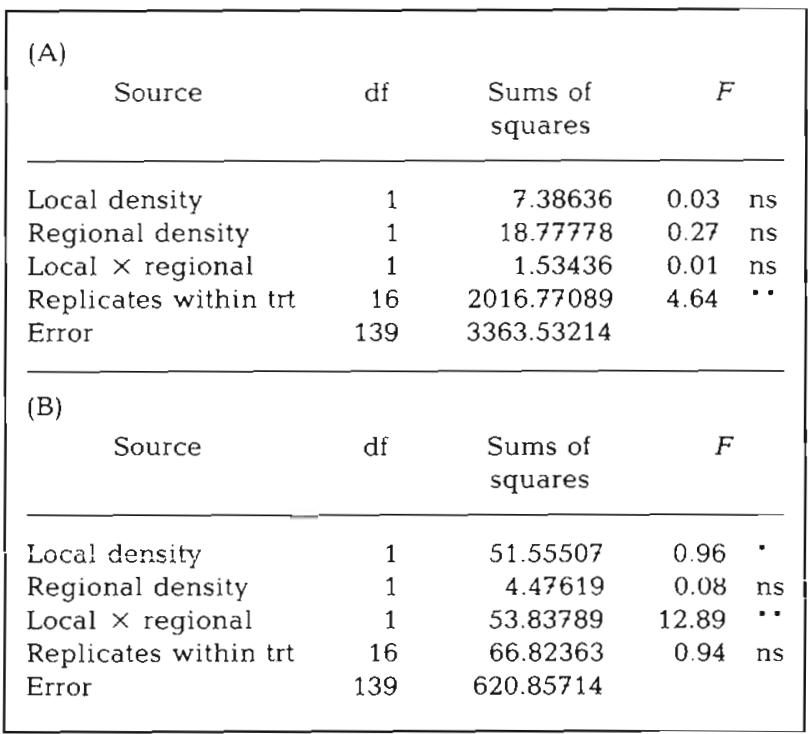

ance in the treatment with no $D$. cuprea. Variation between replicate treatments was not significant (Table 2B). Size frequency data revealed that growth in sites without $D$. cuprea and sites with $D$. cuprea $(3$ treatments with tubes pooled to reflect $M$. lateralis abundance differences) did not differ, modal size being $230 \mu \mathrm{m}$ in each (Fig. 4). However, numbers in the smaller size classes were greatly reduced in the treatments with $D$. cuprea compared to treatments without D. cuprea.

\section{DISCUSSION}

Recruitment of Mulinia lateralis may be viewed in 2 phases in this study: (1) initial recruitment including settlement and a few days post-settlement, and (2) an early post-settlement period of $31 \mathrm{~d}$. The distribution and abundance of $M$. lateralis at the end of the initial phase ( 4 to $8 \mathrm{~d}$ post-settlement) is presumed to be similar to that of settlement, suggesting that settlement abundance was unaffected by the presence of Diopatra cuprea tubes. Early post-settlement mortality was high in all treatments (Table 1), but greater in sites with $D$. cuprea than in site without $D$. cuprea. The result was a spatial pattern of recruitment substantially different from that at settlement.

Artificial and defaunated substrata have been used in recruitment studies (e.g Jackson, 1977; Sutherland and Karlson, 1977; Dean and Hurd, 1980; Kay and Keough, 1981; Eckman, 1983) to delimit the time of 
settlement (all recruits must have settled after introduction or defaunation of the substrate). The interval between introduction or defaunation and sampling is often 1 mo or more. Where shorter intervals have been used and the time of settlement more precisely established (McCall, 1977; Grosberg, 1981; Keough and Downes, 1982; Zajac and Whitlatch, 1982; Eckman, 1983) early post-larval mortality has been observed to affect recruitment patterns. Close observation of settlement into natural communities, however, requires fre-
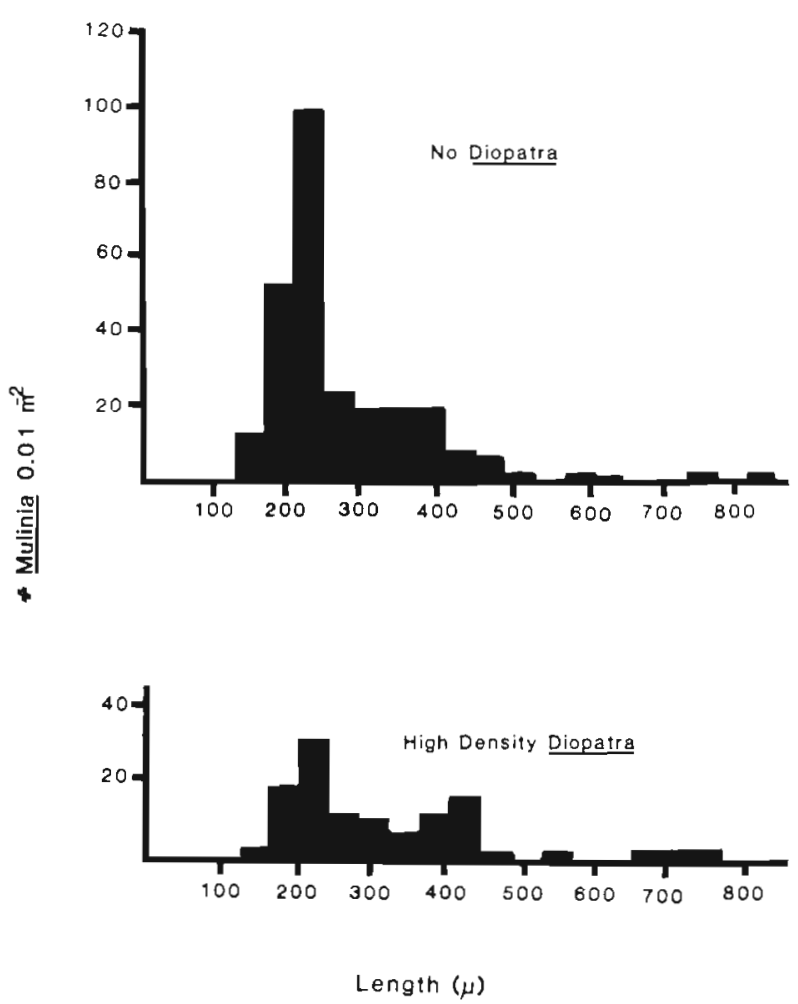

Fig. 4. Mulinia lateralis. Size-frequencies on 18 July, 4 to 5 wk after settlement. The 3 treatments containing Diopatra cuprea are pooled and reported as 'High Density Diopatra'

quent sampling beginning prior to the settlement event.

Most Mulinia lateralis settlement in this study occurred between June 9 and June 13 (Fig. 2). Samples taken on June 17 are therefore a maximum of 8 and a minimum of $4 \mathrm{~d}$ post-settlement. Mean densities of 514 juveniles $0.01 \mathrm{~m}^{-2}$ over the 4 treatments indicate a substantial settlement of $M$. lateralis that was highly variable over the study site, leading to differences among the replicates. The variability was not associated with the presence of Diopatra cuprea tubes (Table 2A). Eckman $(1979,1983)$ found that simulated tubes, singly and in arrays, enhanced larval settlement as a result of hydrodynamic effects, a phenomenon that did not occur with $M$. lateralis larvae around D. cuprea tubes.

The overall reductions in Mulinia lateralis densities observed approximately 1 mo after settlement (Table 1B) may be the result of mortality or emigration (passive and/or active movements). The decrease in $M$. lateralis density was accompanied by a reduction in the variability within a treatment, i.e. between replicate variance decreased (Table 2). Muus (1973) similarly found that spatial variation in the recruitment of several bivalve species leveled off after settlement. The reduced abundances of $M$. lateralis in the $3 D$. cuprea treatments relative to abundances in the treatments without $D$. cuprea (an increase in between habitat variance) must result from processes subsequent to settlement. Whereas the actual magnitude of differences in $M$. lateralis abundances between treatments was small, these differences arose after only the first month post settlement. The data listed under 'Initial Findings' reveal that this pattern of differential abundances becomes accentuated with time.

The precise cause of the reduced Mulinia lateralis abundances in the vicinity of Diopatra cuprea tubes is not clear. $D$. cuprea itself is unlikely to be responsible, because the treatment containing no $D$. cuprea locally but with high regional densities showed the same reduced abundances of $M$. lateralis as did the treatments with high local abundances of $D$. cuprea (Table 1B). D. cuprea forages to a large extent on the epibiota of its tube cap (Mangum et al., 1968), and although individuals will sometimes feed on the sediment surface, this is unlikely to have accounted for the reduced $M$. lateralis abundances where $D$. cuprea is locally absent.

Explanations of community structure based on the effects of established community members on recruitment (Rhoads and Young, 1970; Woodin, 1976; Wilson, 1980; Watzin, 1983) have emphasized post-larval interactions. Virnstein (1977) demonstrated with the use of exclosures that the failure of $M$. lateralis to recruit at some sites in the Chesapeak Bay may result from post-settlement predation/disturbance rather than failure to settle. Poor survival of newly-recruited $M$. lateralis in the vicinity of $D$. cuprea tubes may have resulted from predation/disturbance by other infauna in the community. Alternatively, sites with high densities of tubes may be areas of reduced sediment stability (Eckman et al., 1981), leading to resuspension and washout of small juvenile bivalves in such areas.

The above findings show the hazard of inferring settlement patterns based upon the distribution of earlystage juveniles. The rapidity with which abundance patterns changed indicate not only that young, small individuals must be observed, but also that the time of settlement must be known if we wish to distinguish 
between settlement and post-settlement processes and to discern their effects on subsequent populations structure.

Acknowledgements. I thank N. C. Alon, L. A. J. Clements, R. J. Feller, S. E. Stancyk and S. A. Woodin for critical discussions and reviews of the manuscript. Three anonymous reviewers provided valuable comments. Financial support was provided by the Dept. of Biology and the Baruch Institute at the University of South Carolina.

\section{LITERATURE CITED}

Boesch, D. F. (1973). Classification and community structure of macrobenthos in the Hampton Roads area, Virginia Mar. Biol. 21: 226-244

Boesch, D. F., Wass, M. L, Virnstein, R. W. (1976). The dynamics of estuarine benthic communities. In: Wiley, $M$. L. (ed.) Estuarine processes, Vol. I, Uses, stresses, and adiaptation to the cstuary. Academic Press, New York, p. $177-196$

Cameron, R. A., Schroeter, S. C. (1980). Sea urchin recruitment: effect of substrate selection on juvenile distribution. Mar. Ecol. Prog. Ser. 2: 243-247

Chanley, P., Andrews, J. D. (1971). Aids for indentification of bivalve larvae of Virginia. Malacologia 11: 45-119

Crisp, D. J. (1976). Settlement responses in marine organisms. In: Newell, R. C. (ed.) Adaptations to environment: essays on the physiology of marine organisms. Butterworths, London, p. $83-124$

Dean, T. A., Hurd, L. E. (1980). Development in an estuarine fouling community: the influence of early colonists on later arrivals. Oecologia (Berl.) 46: 295-301

Eckman, J. E. (1979). Small-scale patterns and processes in a soft-substratum, intertidal community. J. mar Res, 37: $437-457$

Eckman, J. E. (1983). Hydrodynamic processes affecting benthic recruitment. Limnol. Oceanogr. 28: 241-257

Eckman, J. E., Nowell, A. R. M., Jumars, P. A. (1981). Sediment destabilization by animal tubes. J. mar. Res. 39: 361-374

Fretter, V., Manly, R. (1977). The settlement and early benthic life of Littorina neritoides (L.) at Wembury, S. Devon. J. mollusc. Stud. 43: 255-262

Grosberg, R. K. (1981). Competitive ability influences habitat choice in marine invertebrates. Nature, Lond. 290: $700-702$

Grosberg, R. K. (1982). Intertidal zonation of bamacles: the influence of planktonic zonation of larvae on vertical distribution of adults. Ecology 63: 894-899

Hannan, C. A. (1981). Polychaete larval settlement: correspondence of patterns in suspended jar collectors and in the adjacent natural habitat in Monterey Bay, California. Limnol. Oceanogr. 26: 159-171

Highsmith, R. C. (1982). Induced settlement and metamorphosis of sand dollar (Dendraster excentricus) larvae in predator-free sites: adult sand dollar beds. Ecology 63: 329-337

Hollander, M., Wolfe, D. A. (1973). Nonparametric statistical methods. Wiley \& Sons, New York

Jackson, J. B. C. (1977). Habitat area, colonization and development of epibenthic community structure. In:
Keegan, B. F., Ceidigh, P. O., Boaden, P. J. S. (ed.) Biology of benthic organisms. Pergamon Press, Oxford, p. 349-358

Kay, A. M., Keough, M. J. (1981). Occupation of patches in epifaunal communities on pier pilings and the bivalve Pinna bicolor at Edithburgh. South Australia. Oecologia (Berl.) 48: 123-130

Keough, M. J., Downes, B. J. (1982). Recruitment of marine invertebrates: the role of active larval choice and early mortality. Oecologia (Berl.) 54: 348-352

Kirk, R. E. (1982). Experimental design. Brooks/Cole Publ. Co., Monterey

Lewis, C. A. (1977). A review of substratum selection in freeliving and symbiotic cirripedes. In: Chia, F.-S., Rice, M. (ed.) Settlement and metamorphosis of marine invertebrate larvae. Elsevier, Amsterdam, p. 207-217

Mangum, C. P., Santos, S. L., Rhodes, W W., Jr. (1968). Distribution and feeding in the onuphid polychaete, Diopatra cuprea (Bosc). Mar. Biol. 2: 33-40

McCall, P. L. (1977). Community patterns and adaptive strategies of the infaunal benthos of Long Island Sound. J. mar. Res. 35: 221-266

Meadows, P. S., Campbell, J. I. (1972). Habitat selection by aquatic inveriebrates. Adv. mar. Biol. 10: 271-382

Muus, K. (1973). Settling, growth and mortality of young bivalves in the Øresund. Ophelia 12: 79-116

Rhoads, D. C., Young, D. K. (1970). The influence of depositfeeding organisms on sediment stability and community structure. J. mar. Res. 28, 150-178

Sarver, D. (1979). Recruitment and juvenile survival in the sea hare Aplysia juliana (Gastropod: Opisthobranchia). Mar. Biol. 54: 353-361

Scheltema, R. S. (1974). Biological interactions determining larval settlement of marine invertebrates. Thalassia jugosI. 10: 263-296

Sokal, R. R., Rolhf, F. J. (1969) Biometry. W. H. Freeman and Co, San Francisco

Sutherland, J. P, Karlson, R. H. (1977). Development and stability of the fouling community at Beaufort, North Carolina. Ecol. Monogr. 47: 425-446

Thorson, G. (1966). Some factors influencing the recruitment and establishment of marine benthic communities. Neth. J. Sea. Res. 3: 267-293

Virnstein, R. W. (1977). The importance of predation by crabs and fishes on benthic infauna in Chesapeake Bay. Ecology 58: $1199-1217$

Watzin, M. C. (1983). The effects of meiofauna on settling macrofauna: meiofauna may structure macrofaunal communities. Oecologia (Berl.) 59: 163-166

Williams, J. G. (1980a). Growth and survival in newly settled spat of the Manila clam, Tapes japonica. Fish. Bull. 77: $891-900$

Williams, J. G. (1980b). The influence of adults on the settlement of spat of the clam. Tapes japonica. J. mar. Res. 38 $729-741$

Wilson, W. H. (1980). A laboratory investigation of the effect of a terebellid polychaete on the survivorship of nereid polychaete larvae. J. exp. mar. Biol. Ecol. 46: 73-80

Woodin, S. A. (1976). Adult-larval interactions in dense infaunal assemblages: patterns of abundance. J. mar. Res. 34: $25-41$

Zajac, R. N. and Whitlach, R. W. (1982). Responses of estuarine infauna to disturbance. I. Spatial and temporal variations in initial recolonization. Mar Ecol. Prog. Ser. $10: 1-14$ 